\title{
ТВАРИННИЦТВО
}

DOI: $10.32636 / 01308521.2021-(70)-2-10$

UDC 636.4:614.9

A. I. DMYTROTSA, postgraduate

Institute of Agriculture of Carpathian Region of NAAS

Hrushevskoho street, 5, v. Obroshyne, Lviv district, Lviv region,

81115,e-mail: andrianadmitroca@gmail.com

\section{METABOLIC PROCESSES IN PIGS AND THEIR PRODUCTIVITY DEPENDING ON THE MICROCLIMATE OF THE PREMISES}

A number of domestic and foreign scientific studies conducted in recent years have shown that the parameters of the microclimate in the premises have a significant impact on the physiological state, the course of metabolic processes in the body and the productive qualities of animals. In animal husbandry, there are certain rules that state that the correct microclimate in the pigsty affects the appetite, health and development of piglets. It should also be noted that different sex-age and productive groups of pigs, and in particular such groups of pigs as pregnant and lactating sows, as well as newborn and weaned piglets, which are most sensitive to the smallest deviations, are particularly sensitive to the negative effects of indoor microclimate parameters. In addition, during the rearing of piglets, it is necessary to create optimal conditions for the most painless passage of stressful phenomena associated with birth, weaning from the sow, change of location, the creation of new hierarchical relationships in the group. For this, innovative technologies are being developed to ensure comfortable microclimate conditions in pig housing at different times of the year.

Based on the above, the maintenance of optimal microclimate parameters along with the appropriate level and quality of feeding are the most important factors for the welfare of animals and their high productivity. Given the constant intensification of the pork production process and climate change in Ukraine, the study of the impact of microclimate parameters on metabolic processes and productive qualities of pigs is relevant and of both scientific and practical interest.

This review article analyzes and summarizes domestic and foreign sources of literature in recent years on the influence of such factors of indoor microclimate as temperature, light, humidity, level of harmful gases, the metabolic processes in pigs and their productivity. The article also provides scientific information related to modern approaches and engineering solutions to correct and improve the microclimate of the premises for keeping different age and productive groups of pigs.

Key words: pigs, indoor microclimate, metabolism, productivity.

\footnotetext{
* Scientific supervisor - Doctor of biological sciences S. O. Vovk.
} 
Дмитроца А. I.

Інститут сільського господарства Карпатського регіону НААН

Метаболічні процеси в організмі свиней та їх продуктивність залежно від мікроклімату приміщень

Низкою вітчизняних і зарубіжних наукових досліджень, проведених в останні роки, доведено, що параметри мікроклімату приміщень виявляють істотний вплив на фізіологічний стан, перебіг обмінних процесів в організмі та продуктивні якості тварин. У тваринництві існують певні правила, які стверджують, що саме правильний мікроклімат у свинарнику впливає на апетит, здоров'я і розвиток поросят. Слід зазначити, що особливо чутливими до негативної дії параметрів мікроклімату приміщень $є$ різні статево-вікові і продуктивні групи свиней, i зокрема такі групи, як поросні i лактуючі свиноматки, а також новонароджені та відлучені поросята, які є найбільш чутливі до найменших їх відхилень. Крім того, під час вирощування поросятам потрібно створити оптимальні умови для якомога більш безболісного проходження стресових явищ, пов'язаних з народженням, відлученням від свиноматки, а також зміною місця утримання та створенням нових ієрархічних відносин у групі. 3 цією метою розробляються інноваційні технології щодо забезпечення комфортних умов мікроклімату в приміщеннях для утримання свиней у різні періоди року.

Виходячи 3 наведеного вище, питання підтримання оптимальних параметрів мікроклімату поряд із належним рівнем i якістю годівлі $\epsilon$ найважливішими факторами для добробуту тварин та їх високої продуктивності. Враховуючи постійну інтенсифікацію процесу виробництва свинини та кліматичні зміни на території України, дослідження впливу параметрів мікроклімату на метаболічні процеси та продуктивні якості свиней $\epsilon$ актуальними і становлять як науковий, так і практичний інтерес.

У цій оглядовій статті проаналізовано та узагальнено вітчизняні та зарубіжні джерела літератури останніх років щодо впливу таких факторів мікроклімату приміщень, як температура, освітленість, вологість повітря, рівень шкодочинних газів на перебіг обмінних процесів в організмі свиней та ïx продуктивність. У статті також наведено наукову інформацію, яка стосується сучасних підходів та інженерних рішень щодо корекції та поліпшення мікроклімату приміщень для утримання різних вікових та продуктивних груп свиней.

Ключові слова: свині, мікроклімат приміщень, обмін речовин, продуктивність.

Introduction. In Ukraine, pig farming is a traditional livestock industry that is constantly evolving. Pork producers are increasingly introducing modern technologies in the selection, feeding and keeping of animals, which significantly increases the productivity of pigs and the quality of their products. 
In the context of the transition of pig farming to an industrial basis, it is necessary to assess all the factors that affect the welfare of animals. Pigs of modern breeds and specialized lines are characterized by high productivity due to genetics. This is the reason for the high sensitivity to the effects of adverse environmental factors. Among these factors the microclimate of rooms occupies important place, and first of all such its factors as temperature and humidity of air, concentration of harmful gases, the general gas structure, pollution by microorganisms, etc.

In recent years, domestic and foreign studies have convincingly proven that the conditions of keeping animals in their importance should be put on a par with the quality of feeding [17].

Thus, according to research of Tunasov A. I., to maintain a normal microclimate in the pigsty, it is necessary constant artificial ventilation. Low air exchange in pig housing can lead to a deterioration of the microclimate, an increase in the content of harmful substances in the air, as well as an increase in moisture and heat. Intensive air exchange in the room where pigs are kept in winter can cause high heat consumption and lower temperatures [19].

It is proved that pregnant and lactating sows are especially sensitive to the disturbance of the microclimate in the premises. According to a number of authors $[1,8,9]$, the productivity of sows depends on both the season of the year and the system of maintaining the microclimate in the room. Thus, A. A. Balnikov [1] found that sows with a higher by $4.5 \%$ fertility were distinguished by combinations $(\mathrm{WB} \times \mathrm{L}) \times \mathrm{D}$, which were fertilized in the spring season, compared with sows of the same genotype, fertilized in summer.

The analysis of differences in the parameters of the microclimate created by two negative pressure systems, different in the method of air preparation, conducted by V. M. Voloshchuk and V. M. Gerasymchuk [6] revealed higher efficiency of geothermal ventilation with air supply through intake shafts and underground air ducts. E. A. Samokhina [18] points out that the geothermal ventilation system created the best microclimate conditions in the pigsty for keeping lactating sows in the autumn, which contributed to the improvement of conservation and intensity of piglets' development.

R. V. Mylostyvyi [10] studied the effect of indoor microclimate on reproductive qualities of sows in the hot period of the year with different ventilation options and found that geothermal ventilation achieves better temperature in the pigsty, which helps to preserve the safety of piglets and increase nest weight during weaning. M. H. Povod [7] notes that the 
uniform pressure ventilation system allows to maintain an optimal microclimate in the room for rearing piglets, but it does not provide uniform air exchange in all areas of the section, so it requires additional measures to normalize air parameters in the warm season.

Potential productivity of pigs due to unsatisfactory zoohygienic conditions is often used only by $70-80 \%$. Therefore, the creation of optimal microclimate parameters in industrial pig farming is the most important reserve for increasing the production of high quality products.

Influence of temperature, illumination and humidity of premises on metabolic processes in the body of pigs of different age groups.

Pigs are very sensitive to heat stress, which is the body's response to high temperatures and causes changes in all systems of animal organs, provoking oxidative stress [15]. Therefore, pig farms constantly monitor the parameters of the indoor microclimate. In particular, special importance is attached to such indicators as: temperature, illuminance, humidity, chemical composition of air, the presence of dust and microbes.

It is known that pigs do not have sweat glands, so thermoregulation in them occurs solely through respiration. They feel comfortable only in a narrow temperature range. The biggest changes due to heat stress occur in the cardiovascular, respiratory systems and gastrointestinal tract. Disorders of the cardiovascular system when the body overheats due to the effects of hyperthermia on the central nervous system. In the heat, the tone of blood vessels and their blood supply changes, tachycardia and arrhythmia develop, blood pressure drops. With increasing activity of the heart during overheating, blood circulation accelerates. At extreme overheating the blood circulation rate decreases, which is explained by the weakening of heart function [20].

Prolonged exposure to high temperatures causes heat stroke. The researchers note that even at a temperature of $+23-25^{\circ} \mathrm{C}$ the intensity of respiration in pigs increases by one and a half times, and the pulse - by 20 30 beats per minute. This increases the neuromuscular excitability, muscle hypertonia may occur until the development of seizures and tetany. Animals become agitated or, conversely - depressed [13].

Significant changes due to heat stress also occur in the gastrointestinal tract of pigs. In particular, under the action of high temperatures there is a suppression of the secretion of gastric juice: there is a lack of its bactericidal function, reduced pepsin activity and increased concentration of total protein. The greatest inhibition is experienced by the proteolytic group of enzymes - pepsin, trypsin, enterokinase, which worsens the digestive processes and reduces the rate of absorption of amino 
acids. There is an inhibition of the secretion of pancreatic enzymes, intestinal motility is suppressed. Accordingly, appetite is reduced, and hence productivity. If at a temperature of $+15-17^{\circ} \mathrm{C}$ per $40 \mathrm{~kg}$ of live weight gain $120-140 \mathrm{~kg}$ of feed is needed, then at $+29^{\circ} \mathrm{C}$ to obtain a similar increase $-480 \mathrm{~kg}$. [15, 28].

Another important indicator of the microclimate of livestock facilities is the relative humidity, which also has a significant impact on the development of pigs. Changing the relative humidity from 70 to $95 \%$ leads to an increase in pig waste from 0.05 to $17.5 \%$. High relative humidity in the premises reduces the digestibility of nutrients. The average daily gain of pigs on rearing at a relative humidity of $85 \%$ is $653 \mathrm{~g}$, and at $91.8 \%$ - only $553 \mathrm{~g}$ [9].

Humidity and temperature are interrelated and together affect the thermoregulation and metabolism of the animal, they are inversely related. In the premises for pigs, the relative humidity varies from 50 to $90 \%$, and sometimes up to $100 \%$ (in winter and transitional periods of the year) [17]. The relative humidity in the room for keeping pigs should be in the range of $60-80 \%$, and the maximum allowable $-85 \%$ [9].

N. O. Beloziorova's research showed that when pigs are kept under conditions of lower air temperature $\left(10-13^{\circ} \mathrm{C}\right)$ and increased relative humidity (up to $72-75 \%$ ) it has a negative effect on the status of their natural resistance [3].

An important factor in the comfortable keeping of pigs indoors is lighting. At the same level of feeding in pigs when kept in a dark room, $15 \%$ more subcutaneous fat accumulates compared to animals that are constantly in daylight. Prolonged, round-the-clock lighting of the premises causes in pigs suppression of their productivity $[31,36]$.

One of the ways to increase the productivity and quality of pig products, especially in industrial complexes, is the use of regular ultraviolet radiation. The use of the latter has a positive effect on metabolic processes, increases meat yield, improves its nutritional value, increases the content of dry matter, total nitrogen, glycogen in the musculus longissimus dorsalis. In the skin of animals under the action of ultraviolet light undergoes formation of vitamin D from its food precursors. [2, 33]

Influence of harmful gases on metabolic processes in pigs. Excessive concentrations of harmful gases are known to be toxic and can cause health problems in both humans and animals. Manure is the biggest source of contamination in pig housing. From it, four main dangerous gases are released into the atmosphere - hydrogen sulfide, methane, ammonia and carbon dioxide $[8,11]$. 
The results of numerous studies show that in livestock facilities, excessive levels of ammonia, hydrogen sulfide, carbon dioxide in the air reduces the productivity of animals and increases the percentage of culling, as well as increases the level of feed consumption per unit of production [24].

It should be emphasized that in the conditions of unsatisfactory microclimate in pigs, the natural resistance and immunological reactivity of their organism decreases. In addition, increased amounts of harmful gases in piggeries significantly affects the health of staff, as well as reduces the service life of equipment and machinery [16, 22].

In livestock facilities, the air in its chemical composition differs significantly from the surrounding as a result of the release of various gases from animal respiration and decomposition of manure. During the respiration of animals, a large amount of carbon dioxide is released, and oxygen is absorbed, while as a result of biochemical reactions that take place in manure, a significant amount of ammonia, carbon dioxide, hydrogen sulfide and other harmful gases with unpleasant odor is released into the air. [21].

It is established that during long stay of animals in the environment with the increased content of harmful gases they can have various deviations and disorders of a metabolism. Methane $\left(\mathrm{CH}_{4}\right)$, carbon dioxide $\left(\mathrm{CO}_{2}\right)$, ammonia $\left(\mathrm{NH}_{4}\right)$ and hydrogen sulfide $\left(\mathrm{H}_{2} \mathrm{~S}\right)$ are considered to be the main harmful gaseous impurities in the air of livestock premises [12, 35]

In addition to the above-mentioned harmful gases in the premises for keeping pigs with improper ventilation accumulate substances that contribute to the unpleasant odor (skatol, mercaptan, etc.). Their level cannot yet be measured with instruments, but their presence can be determined organoleptically [7]. Scatol is formed from tryptophan during bacterial decomposition of protein and gives animal feces a specific odor. Mercaptans are alcohols in which the oxygen atom of the hydroxyl group $(\mathrm{OH})$ is replaced by sulfur with an unpleasant odor [26].

Elevated levels of methane, carbon dioxide, ammonia and hydrogen sulfide are a danger to animal health in pig housing. A gas such as methane is odorless, but at excessive concentrations it is an invisible enemy to human and animal health in particular [7]. Methane poisoning can lead to rapid heartbeat, pulmonary edema and shortness of breath.

Carbon dioxide is also dangerous - a colorless, non-flammable substance with a slightly acidic odor and taste. It is a product of metabolism and is excreted mainly during animal respiration, partially formed during the decomposition of feces and feed residues. The release of $\mathrm{CO}_{2}$ by 
animals depends on their species, age, feeding and productivity. High concentrations of carbon dioxide in livestock premises lead to impaired respiratory function of animals, and with prolonged exposure causes depression, lethargy, reduced productivity, resistance of animals and even chronic poisoning [7]. Accumulation of excessive $\mathrm{CO}_{2}$ in the air of livestock premises is eliminated by proper installation and use of ventilation equipment. By ventilating the premises, when the relative humidity is maintained within acceptable limits, there is no increased concentration of $\mathrm{CO}_{2}$.

More harmful to pigs is ammonia, which has a pronounced pungent odor and is felt even at low concentrations. It can damage the eyes and respiratory tract, thereby causing chemical burns [26, 27]. At high concentrations, it can cause corneal ulcers and cause nausea, vomiting, palpitations and seizures [30]. According to Z. Cheng and E. A. O'Connor, pigs are often exposed to elevated concentrations of ammonia, which is considered an environmental stressor that slows growth and causes poor animal health [25].

The results obtained by M. O. Parker, suggest that ammonia, even in acceptable concentrations when combined with the factor of insufficient indoor lighting, can impair the physiological condition and productivity of pigs [36].

According to the findings of R. R. Manuel, the concentration of ammonia in farrowing rooms in the area of animal life varies depending on the set temperature for the climate control system. At night, when the air temperature is lower, the ventilation rate decreases, which causes an increase in the concentration of ammonia. Increasing the outside temperature during the day increases the speed of ventilation and, consequently, the speed of gas removal. The highest concentrations of ammonia occur at night, and the lowest - during the day [29].

Studies by Z. Ye and G. Zhang [23] found that the coefficient of ammonia emissions in the premises is significantly reduced with proper ventilation.

$\mathrm{W}$. Xu and $\mathrm{K}$. Zheng, studying gas emissions from pig farms, found that average ammonia emissions were highest in spring and summer and lowest in autumn and winter. The average ammonia emissions per area $\left(\mathrm{m}^{2}\right)$ of farrowing room were almost three times higher in the summer months than in the winter [24].

The main source of hydrogen sulfide formation in the premises is bacterial decay of high-protein products of plant and animal origin, primarily in the manure mass [34]. Hydrogen sulfide is a dangerous poison 
for the circulatory and nervous systems in animals, because when it enters the bloodstream through the lungs, it inhibits the activity of enzymes that are necessary for cell respiration and thus causes paralysis of the respiratory system [14].

Hydrogen sulfide $\left(\mathrm{H}_{2} \mathrm{~S}\right)$ is considered the most dangerous decomposition product of manure and has a pronounced smell of rotten eggs. At low concentrations it irritates the eyes and respiratory tract, while at slightly higher concentrations hydrogen sulfide causes headache, dizziness and nausea [12]. At high concentrations, hydrogen sulfide paralyzes the nerve cells of the nose. The consequences of prolonged inhalation of hydrogen sulfide in small quantities can lead to acute respiratory failure and as a consequence to the death of animals. [35].

Modern effective ways to improve the microclimate of pig housing. In modern domestic pig breeding, various technological approaches are used to properly ensure the parameters of the microclimate in the premises. All these systems have certain advantages and disadvantages and have the right to exist. And in each case, when designing a new or reconstructed complex, specialists have difficulty choosing a system. Most often, this choice is based on established advantages in the equipment, pricing policy of the equipment supplier, the desire to replicate ready-made design solutions.

The most important component of the system of providing comfortable conditions for keeping pigs is ventilation, which should provide optimal air temperature, quality and humidity, regardless of climatic conditions. Ventilation should solve the following tasks: maintain the temperature and humidity at the optimal level for pigs, removing excess heat and moisture from the room; create air exchange in the room, providing animals with fresh air, but not creating drafts; evenly distribute the air in the room, meeting the need of all animals for ventilation; to prevent possible threats to the health of pigs in the event of a power outage and ventilation failure; to provide optimal production indicators and results [11].

In the reconstructed premises of pig farms, natural ventilation provides the necessary temperature and humidity in the necessary parameters in winter and transition periods under conditions of sufficient sealing of the premises. In summer, the creation of a microclimate in the premises for keeping pigs within the hygienic standards is possible only with a combination of natural and artificial ventilation [2]. 
Modern domestic and foreign ventilation systems for pigs include different options. The first of them is ventilation with supply valves in the walls. It works satisfactorily in temperate climates $\left(-15\right.$ to $\left.+22^{\circ} \mathrm{C}\right)$.

The second ventilation system provides for the presence of perforated ceilings in the premises, the so-called diffusion ventilation. The negative pressure created by the exhaust fans inside the premises causes the inflow of outside air into the attic space through the openings under the roof [22].

In the premises for keeping animals, the inflow of outside air can be carried out by active supply recirculation shafts installed in the floor. Air is removed from the room through active exhaust shafts. The main advantage of this system is that the external cold air entering the supply shaft is mixed in it with the room air, increasing the temperature of the supply air at the outlet of the distributor [16].

Another type of ventilation system is a system of centralized ventilation with the organization of supply and exhaust ducts in the basement - the so-called underground ventilation system. This system provides low values of air exchange (up to $0.6 \mathrm{~m}^{3} / \mathrm{kg}$ live weight). The massive underground system of concrete channels plays the role of a heat accumulator, thus smoothing daily temperature fluctuations [9].

Currently, the most cost-effective is system of ventilation of negative pressure inside the room using the supply of cold air from top to bottom with the help of exhaust fans and computer climate control [18].

An important element in providing comfortable conditions for keeping pigs is cooling the air in the premises, especially in the summer under conditions of global warming. It is known that the buildings of pig farms due to the action of solar radiation, high ambient temperature and heat release by animals in summer overheat. Due to physiological features, namely due to the absence of sweat glands, pigs do not sweat and therefore negatively tolerate high temperatures. They can compensate low temperatures by a partial decrease in productivity and higher feed consumption [12]. Due to suffocation and overheating, animals grow more slowly, boars' sperm quality deteriorates significantly, and sows are less likely to hunt, fertilize and feed their piglets. Pigs can even have a stress syndrome, which greatly complicates the work of all body systems.

To optimize the conditions of the microclimate in the premises for keeping animals, practitioners are advised to use the formula: the sum of temperature and humidity should not exceed 90 . To reduce the temperature of air supplied to the pigsty and ensure the required ventilation rate use air conditioning systems. 
An effective way to reduce the air temperature in pig farms is adiabatic cooling - humidification of air flows with water sprayed under high pressure. Irrigation systems are used for this purpose. These plants use cold water from artesian wells with a temperature of $+5-+8^{\circ} \mathrm{C}$. Water is supplied under a certain pressure, sprayed with nozzles with the formation of small drops [32].

Conclusions. Creating comfortable conditions is one of the main components of modern intensive pork production. Therefore, optimization of microclimate parameters in pig housing (air temperature, light, humidity, level of harmful gases) is one of the most important factors to fully ensure the metabolism in animals, increase their productive qualities and obtain high quality pork.

\section{Список використаної літератури}

1. Бальников А. А. Влияние сезона осеменения на репродуктивные качества свиноматок. Farm-Animals : научнопрактический журнал. 2014. № 3. С. 5055 .

2. Безмен В. А., Рудаковская И. И., Ходосовский Д. Н. Использование тёмных инфракрасных обогревателей при выращивании поросят-отъёмышей. Зоотехническая наука Беларуси. 2016. Т. 51, № 2. C. 138-144.

3. Бєлозьорова Н. О. Впливи середовища та інноваційних технологій утримання, що докорінно (цілеспрямовано) впливають на стан продуктивності та життездатності свиней. Науковий вісник ЛНУВМБТ імені С. 3. Гжицького. 2014. Т. 16, № 3 (60), ч. 3. C. 255-271.

4. Березовский Н. Д., Почерняев Ф. К., Коротков В. А. Методика моделирования индексов для использования их в селекции свиней. Методы улучшения процессов селекиии, разведения и воспроизводства свиней (методические указания). Москва, 1986. C. 3-14.

5. Важливість вентиляції в сучасному свинарстві. 2020. URL: https://agroclimate.com.ua/images/headers/ 6.pdf (дата звернення: 09.07.2021).

6. Волощук В. М., Герасимчук В. М.

\section{References}

1. Balnikov A. A. Influence of the breeding season on the repro-ductive qualities of sows. Farm Animals : nauchnoprakticheskii zhurnal. 2014. No 3. P. 50-55.

2. Bezmen V. A., Rudakovskaia I. I., Khodosovskyi D. N. Use of dark infrared heaters for weaning pigs. Zootekhnicheskaia nauka Belarusi. 2016. Vol. 51, No 2. P. 138-144.

3. Bieloziorova N. O. Influences of the environment and innovative technologies of keeping that radically (purposefully) affect the state of productivity and viability of pigs. Naukovyi visnyk LNUVMBT imeni S. Z. Gzhytskoho. 2014. Vol. 16, No 3 (60), part 3. P. 255-271.

4. Berezovskyi N. D., Pocherniaev F. K., Korotkov V. A. A technique for modeling indices for use in pig breeding. Methods for improving the processes of selection, breeding and reproduction of pigs (guidelines). Moscow, 1986. P. 3-14.

5. Ventilation is important thing in modern pig farming. 2020. URL: https://agroclimate.com.ua/images/headers/ 6.pdf (last accessed: 09.07.2021).

6. Voloshchuk V. M., Herasymchuk V. M. Indicators of the microclimate in the department for rearing piglets, depending on the method of ventilation. Visnyk ahrarnoi nauky Prychornomoria. 2017. Issue 1 (93). P. 120-128. 
Показники мікроклімату у відділенні для дорощування поросят залежно від способу вентилювання приміщення. Вісник аграрної науки Причорномор'я. 2017. Вип. 1 (93). С. 120-128.

7. Динаміка параметрів мікроклімату у приміщеннях для дорощування поросят залежно від їх маси / М. Г. Повод та ін. Вісник Сумського національного аграрного університету. Тваринництво. 2017. Вип. 7 (33). С. 154 159.

8. Жижка С. В., Повод М. Г., Самохіна Є. А. Залежність параметрів мікроклімату та продуктивності лактуючих свиноматок і росту підсисних поросят від різних систем вентиляції у зимову пору року. Вісник Сумського національного аграрного університету. Тваринництво. 2018. Вип. 7 (35). С. $268-$ 285.

9. Игнаткин И. Ю., Курячий М. Г. Системы вентиляции и влияние параметров микроклимата на продуктивность свиней. Вестник НГИЭИ. 2012. № 10 (17). С. 16-34.

10. Милостивий Р. В. Вплив мікроклімату в приміщенні на відтворювальні якості свиноматок. Матеріали регіональної науковопрактичної конференції «Проблеми та шллхи інтенсифікації виробництва продукиії тваринництва», 15 берез. 2018 p. Херсон : ОЛДІ-ПЛЮС, 2018. С. $127-$ 131.

11. Милостивий Р. В., Повод М. Г., Самохіна Є. А. Параметри мікроклімату в свинарських приміщеннях влітку за різних систем вентиляції та їхній вплив на продуктивність лактуючих свиноматок і ріст підсисних поросят. Вісник Сумського національного аграрного університету. Тваринництво. 2018. Вип. 2 (34). С. 218-223.

12. Михалко О. Г., Повод М. Г. Сезонна залежність продуктивності свиноматок данського походження від конструктивних особливостей систем вентиляції приміщень у період опоросу та лактації. Вісник Сумського
7. Dynamics of microclimate parameters in the premises for rearing piglets depending on their weight / M. H. Povod et al. Visnyk Sumskoho natsionalnoho ahrarnoho universytetu. Tvarynnytstvo. 2017. Issue 7 (33). P. 154 159.

8. Zhyzhka S. V., Povod M. H., Samokhina Ye. A. Dependence of microclimate parameters, productivity of lactating sows and growth of suckling piglets on different ventilation systems in winter. Visnyk Sumskoho natsionalnoho ahrarnoho universytetu. Tvarynnytstvo. 2018. Issue 7 (35). P. 268-285.

9. Ignatkin I. Yu., Kuriachyi M. H. Ventilation systems and the influence of microclimate parameters on the productivity of pigs. Vestnik NHIEI. 2012. No 10 (17). P. 16-34.

10. Mylostyvyi R. V. Influence of indoor microclimate on reproductive qualities of sows. materialy rehionalnoi naukovo-praktychnoi konferentsii: «Problemy ta shliakhy intensyfikatsii vyrobnytstva produktsii tvarynnytstva», 15 berez. 2018 r. Kherson : OLDI-PLIUS, 2018. P. 127-131.

11. Mylostyvyi R. V., Povod M. H., Samokhina Ye. A. Parameters of microclimate in piggeries in summer with different ventilation systems and their impact on the productivity of lactating sows and the growth of suckling piglets. Visnyk Sumskoho natsionalnoho ahrarnoho universytetu. Tvarynnytstvo. 2018. Issue 2 (34). P. 218-223.

12. Mykhalko O. H., Povod M. H. Seasonal productivity dependence of Danish origin sows on the design features of ventilation systems during farrowing and lactation. Visnyk Sumskoho natsionalnoho ahrarnoho universytetu. Tvarynnytstvo. 2019. Issue 3 (38). P. 77-90.

13. Novykova N. V. Morphological aspects of the interaction of the pituitary gland and adrenal glands under the influence of stress factors. Tavriiskyi naukovyi visnyk. 2013. Issue 84. P. 199203. 
начіонального аграрного університету. Тваринництво. 2019. Вип. 3 (38). С. 7790 .

13. Новикова Н. В. Морфологічні аспекти взаємодії гіпофіза і наднирників під впливом стрес-фактора. Таврійський науковий вісник. 2013. Вип. 84. С. 199203.

14. Повод М. Г., Корж О. В., Нестеров А. М. Вплив пори року на відтворні якості свиноматок данської селекції. Вісник Сумського національного аграрного університету. Тваринництво. 2017. Вип. 5 (2). С. 111-113.

15. Пономаренко В. М. Амінокислотний склад м'язової тканини свиней різних генотипів. Зоотехнічна наука: історія, проблеми, перспективи : Міжнар. наук.-практ. конф., 16-18 берез. 2011 р. Кам'янець-Подільський, 2011. С. 193-194.

16. Расмуссен К. Система вентиляції як елемент біобезпеки господарств. Прибуткове свинарство. 2019. Вип. № 3 (51).

URL: http://profisvine.pigua.info/indexukr.php?ac tion=issue\&id (дата звернення: 11.07.2021).

17. Ресурсозберігаючі технології виробництва свинини: теорія і практика: навч. посіб. / Царенко О. М. та ін. ; за ред. О. М. Царенка. Суми : ВТД «Університетська книга», 2004. 269 с.

18. Самохіна Є. А. Продуктивність підсисних свиноматок залежно від параметрів мікроклімату, створеного різними системами вентиляції в осінній період. Аграрна наука та освіта в XXI столітті: проблеми, перспективи та інновації : матеріали Міжнародної науково-практичної конференції, 26-27 квітня 2018 р. Ніжин, 2018. С. 42-48.

19. Тунасов А. И., Галиева Ч. Р. Расчет воздухообмена в свинарникеоткормочнике. Международный студенческий научный вестник. 2019. № 1.

URL:

https://eduherald.ru/ru/article/view?id=1956 2 (дата обращения: 11.07.2021).

20. Хохрин С. Н. Корма и кормление
14. Povod M. H., Korzh O. V., Nesterov A. M. Influence of the season on the reproductive qualities of Danish selection sows. Visnyk Sumskoho natsionalnoho ahrarnoho universytetu. Tvarynnytstvo. 2017. Issue 5 (2). P. 111113.

15. Ponomarenko V. M. Amino acid composition of pig muscle tissue of different genotypes. Zootekhnichna nauka: istoriia, problemy, perspektyvy : Mizhnar. nauk.-prakt. konf., 16-18 berez. 2011 r. Kamianets-Podilskyi, 2011. P. 193-194.

16. Rasmussen K. Ventilation system as an element of biosafety of farms. Prybutkove svynarstvo. 2019. Issue No 3 (51).

URL:

http://profisvine.pigua.info/indexukr.php?ac

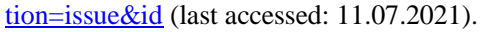

17. Resource-saving technologies of pork production: theory and practice : navch. Posib. / Tsarenko O. M. et al. ; za red. O. M. Tsarenka. Sumy : VTD «Universytetska knyha», 2004. 269 p.

18. Samokhina Ye. A. Productivity of suckling sows depending on the parameters of the microclimate created by different ventilation systems in the autumn. Ahrarna nauka ta osvita $v$ XXI stolitti: problemy, perspektyvy ta innovatsii : materialy Mizhnarodnoi naukovo-praktychnoi konferentsii, 26-27 kvit. 2018 r. Nizhyn, 2018. P. 42-48.

19. Tunasov A. I., Halieva Ch. R. Calculation of air exchange in a fattening pigsty. Mezhdunarodnyi studencheskyi nauchnyi vestnyk. 2019. No 1. URL: https://eduherald.ru/ru/article/view?id=1956 2 (last accessed: 09.07.2021).

20. Khokhrin S. N. Animal feed and feeding. Sankt-Peterburg, 2002. 512 p.

21. Tsereniuk O. M., Khvatov A. I., Stryzhak T. A. Evaluation of the indices effectiveness of maternal productivity of pigs. Suchasni problemy selektsii, rozvedennia ta hihiieny tvaryn : zb. nauk. prats Vinnytskoho NAU. 2010. No 3 (42). P. 73-77.

22. Chernova S. E., Kazakov V. S. 
животных. Санкт-Петербург, 2002. 512 с. 21. Церенюк О. М., Хватов А .I., Стрижак Т. А. Оцінка ефективності індексів материнської продуктивності свиней. Сучасні проблеми селекції, розведення та гігієни тварин : зб. наук. праць Вінницького НАУ. 2010. № 3 (42). C. $73-77$.

22. Чернова С. Е., Казаков В. С. Влияние микроклимата в помещении на рост, развитие и откормочные качества молодняка свиней. Известия ОГАУ. 2014. № 6 (50). C. 127-129.

23. Ammonia emissions affected by airflow in a model pig house: effects of ventilation rate, floor slat opening, and headspace height in a manure storage pit / Ye Z. et al. Transactions of the ASABE. 2008. Issue 51 (6). P. 2113-2122.

24. Atmospheric $\mathrm{NH}_{3}$ dynamics at a typical pig farm in China and their implications / Xu W. et al. Atmospheric Pollution Research. 2014. Issue 3, vol. 5. P. 455-463.

25. Chronic ammonia exposure does not influence hepatic gene expression in growing pigs / Cheng Z. et al. Animal. 2014. Issue 8 (2). P. 331-337.

26. Effect of climate and insemination technique on reproductive performance of gilts and sows in a subtropical zone of Mexico / Mellado M. et al. Austral. Journal of Veterinary Sciences. 2018. Issue 50 (1). P. 27-34.

27. Effect of temperature and humidity on reproductive performance of crossbred sows in Thailand / Suriyasomboon A. et al. Theriogenology. 2006. Issue 65. P. 606628.

28. Emissions of ammonia, methane and nitrous oxide from pig houses and slurry: Effects of rooting material, animal activity and ventilation flow / Blanes-Vidal V. et al. Agriculture, Ecosystems \& Environment. 2008. Issue 124 (3). P. 237244.

29. Evolution of $\mathrm{NH}_{3}$ Concentrations in Weaner Pig Buildings Based on Setpoint Temperature / Manuel R. R. et al. Agronomy. 2020. Issue 10 (1). P. 2-14.
Influence of indoor microclimate on the growth, development and fattening qualities of young pigs. Izvestiia OGAU. 2014. No 6 (50). P. 127-129.

23. Ammonia emissions affected by airflow in a model pig house: effects of ventilation rate, floor slat opening, and headspace height in a manure storage pit / Ye Z. et al. Transactions of the ASABE. 2008. Issue 51 (6). P. 2113-2122.

24. Atmospheric $\mathrm{NH}_{3}$ dynamics at a typical pig farm in China and their implications / Xu W. et al. Atmospheric Pollution Research. 2014. Issue 3, vol. 5. P. 455-463.

25. Chronic ammonia exposure does not influence hepatic gene expression in growing pigs / Cheng Z. et al. Animal. 2014. Issue 8 (2). P. 331-337.

26. Effect of climate and insemination technique on reproductive performance of gilts and sows in a subtropical zone of Mexico / Mellado M. et al. Austral. Journal of Veterinary Sciences. 2018. Issue 50 (1). P. 27-34.

27. Effect of temperature and humidity on reproductive performance of crossbred sows in Thailand / Suriyasomboon A. et al. Theriogenology. 2006. Issue 65. P. 606628.

28. Emissions of ammonia, methane and nitrous oxide from pig houses and slurry: Effects of rooting material, animal activity and ventilation flow / Blanes-Vidal V. et al. Agriculture, Ecosystems \& Environment. 2008. Issue 124 (3). P. $237-$ 244.

29. Evolution of $\mathrm{NH}_{3}$ Concentrations in Weaner Pig Buildings Based on Setpoint Temperature / Manuel R. R. et al. Agronomy. 2020. Issue 10 (1). P. 2-14.

30. Janse van Rensburg L., Spencer B.T. The influence of environmental temperatures on farrowing rates and litter sizes in South African pig breeding units. Onderstepoort J. Vet. Re. 2014. Issue 81. P. $1-7$.

31. Noblet J., Le Dividich J., Van Milgen J. Thermal Environment and Swine Nutrition. Swine Nutrition. 2001. Issue 2. P. 
30. Janse van Rensburg L., Spencer B.

T. The influence of environmental temperatures on farrowing rates and litter sizes in South African pig breeding units. Onderstepoort J. Vet. Re. 2014. Issue 81. P. $1-7$.

31. Noblet J., Le Dividich J., Van Milgen J. Thermal Environment and Swine Nutrition. Swine Nutrition. 2001. Issue 2. P. 519-545.

32. Potential of Geothermal and Ground Channel System House on Reduction of Energy Consumption and $\mathrm{CO}_{2}$ Emissions with Maintenance of Performance of Growing Pigs / Rubayet Bostami A. B. M. et al. International Journal of Recent Scientific Research. 2016. Issue 2, vol. 7. P. 8974-8979.

33. Production responses of weaned pigs after chronic exposure to airborne dust and ammonia / Wathes C. M. et al. Animal Science. 2004. Issue 78 (1). P. 87-98.

34. Reproductive performance of purebred Swedish landrace and Swedish Yorkshire sows: I. Seasonal variation and parity influence / Tummaruk P. et al. Acta Agric. Scand. Sect. A - Anim. Sci. 2010. Issue 50. P. 205-216.

35. Seasonal variation in the ovarian function of sows / Bertoldo M. J. et al. Reprod. Fertil. Dev. 2012. Issue 24. P. 822834.

36. The impact of chronic environmental stressors on growing pigs, Sus scrofa (Part 2): Social behaviour / Parker M. et al. Animal. 2010. Issue 4 (11). P. 1910-1921.
519-545.

32. Potential of Geothermal and Ground Channel System House on Reduction of Energy Consumption and $\mathrm{CO}_{2}$ Emissions with Maintenance of Performance of Growing Pigs / Rubayet Bostami A. B. M. et al. International Journal of Recent Scientifi Research. 2016. Issue 2, vol. 7. P. 8974-8979.

33. Production responses of weaned pigs after chronic exposure to airborne dust and ammonia / Wathes C. M. et al. Animal Science. 2004. Issue 78 (1). P. 87-98.

34. Reproductive performance of purebred Swedish landrace and Swedish Yorkshire sows: I. Seasonal variation and parity influence / Tummaruk P. et al. Acta Agric. Scand. Sect. A - Anim. Sci. 2010. Issue 50. P. 205-216.

35. Seasonal variation in the ovarian function of sows / Bertoldo M. J. et al. Reprod. Fertil. Dev. 2012. Issue 24. P. 822 834.

36. The impact of chronic environmental stressors on growing pigs, Sus scrofa (Part 2): Social behaviour / Parker M. et al. Animal. 2010. Issue 4 (11). P. 1910-1921.

Received 16.08.2021 